Dept. of Biochemistry,

Animal Health Research Institute, Mansoura Lab.

\title{
CHEMICAL EVALUATION OF MEAT AND MEAT PRODUCTS
}

(With 3 Tables)

By

AZZA E.A. HASSAN and OMAMA A.

(Received at 4/6/2011)

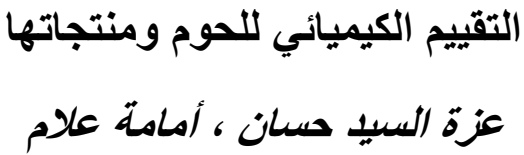

أجريت هذه الدر اسة بهدف تقييم اللحوم ومنتجاتها كيميائيا فقد تم تجميع عدد 25 مو 25 عينة من

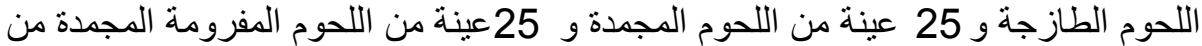

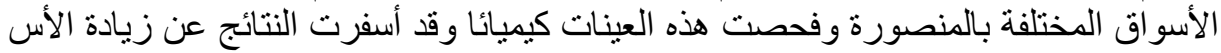

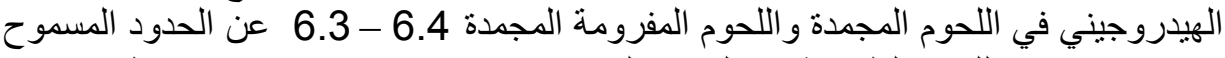

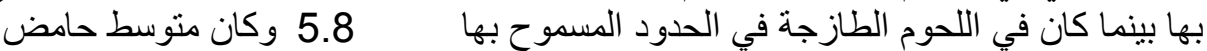

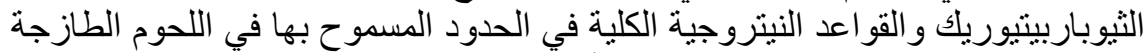

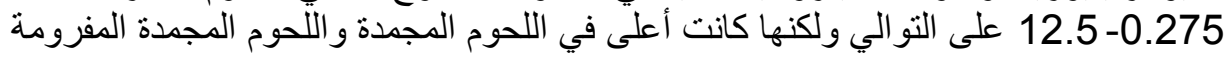

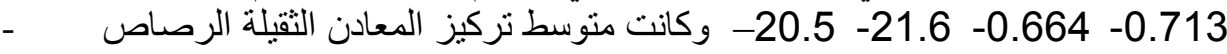

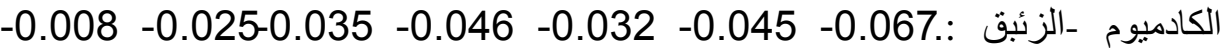

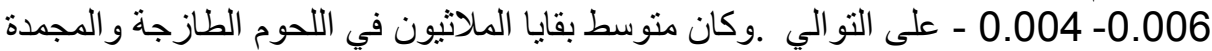

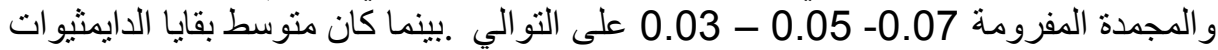

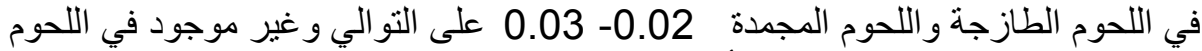

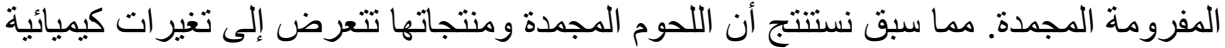

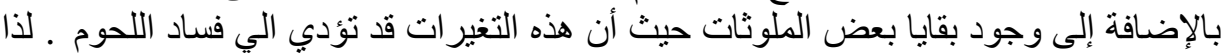

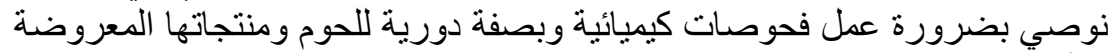

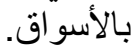

\section{SUMMARY}

The aim of this study was to evaluate meat and meat products chemically. About 25 samples of fresh meat, 25 samples of frozen meat and 25 samples of frozen minced meat were collected from different markets in Mansoura City. All these samples were chemically examined. Data analysis revealed an increase of $\mathrm{pH}$ in Frozen meat and frozen minced meat with the means 6.4 and 6.3 respectively, while the $\mathrm{pH}$ was normal in fresh meat with the mean 5.8. In respect to total volatile basic 
nitrogen (TVB-N) and thiobarbituric acid (TBA), they were in normal levels in fresh meat with the means 12.5 and 0.275 respectively. While in frozen meat and frozen minced meat their vaules increased with the means 21.6and 0.713 , 20.5and 0.664 respectively. Regarding heavy metals concentration the mean values of lead, cadmium and mercury in fresh meat were $0.067,0.046$ and $0.008 \mathrm{ppm}$ respectively. In frozen meat the means were $0.045,0.035$ and $0.006 \mathrm{ppm}$ respectively, while in frozen minced meat were $0.032,0.025$ and $0.004 \mathrm{ppm}$ respectively. Concerning malathion residues in fresh meat, frozen meat and frozen minced meat the mean values were $0.07,0.05$ and 0.03 respectively, while diamethoate residues were with the means 0.02 and 0.03 in fresh and frozen meat respectively and not be detected in frozen minced meat. It can be concluded that meat and meat products are able to be exposed to chemical changes, in addition to presence of some pollutants residues, these changes may lead to spoilage of meat and may constitute public health hazards, so meat and meat products in markets must be examined frequently.

Key words: Meat, meat products, heavy metals, chemical contaminants.

\section{INTRODUCTION}

Contamination of meat includes toxic metals and elements, organometalic compounds and agricultural chemicals. These contaminants may present a potential hazard for human health if exposure exceeds tolerable levels (Turi-szerletics and Patko, 2008).

Heavy metals pollution is considered as one of the most important environmental problems in Egypt. It results from industrial and agricultural wastes that spread in air, water and soil, these pollutants have tendency to accumulate in tissues of animals (Lars, 2003). Cumulative toxic effect of heavy metals are recognized due to low elimination rates from the body and cause serious health hazard to human depending on their level of contamination (Massade and Snook, 2002).

The toxic elements cadmium, lead and mercury are widely distributed in the environment and generally regarded as accidental pollutants although they are frequently found in minute amounts in food (Lucis et al., 1972; Underwood, 1977). Cadmium is used extensively in the mining and electroplating industries and found in fertilizers and fungicides. All its chemical form are toxic (Fleischer et al., 1974). It inhibits sulphydryl enzyme systems necessary for cellular metabolism 
(Gunn and Gould, 1957).

Lead is used in many industrial processes; lead paint and lead gasoline. It is a common material for spraying fruit trees. Absorbed lead accumulates in tissues of the animals. Lead inhibits the activity of enzymes dependent upon the presence of free sulphydryl groups for their activity and this inhibition is clearly demonstrated in disturbances which occur in the biosynthesis of heme (Klauder and Petering, 1975; Willoughby et al., 1976). Mercury was used as fungicides and mercurial fungicides used for seed dressing. Toxic compounds of mercury accumulate in animal tissues. The alkyl mercuries are slowly metabolized and more evenly distributed in the body tissues (Underwood, 1977).

The main side effect of the environmental pollution by pesticides in food contamination leading to injury of non target organisms concerns the health of the workers and consumers. Organophosphrus are used in large scale especially in agricultural and veterinary field nowadays around the world (O'Malley, 1997).

Therefore the aim of this work was to detect heavy metals as lead, cadmium and mercury, as well as to determine hydrogen ion concentration, total volatile basic nitrogen and thiobarbituric acid in meat and meat products exposed for sale in Mansoura markets

\section{MATERIALS and METHODS}

\section{Sampling}

25 fresh meat, 25 frozen beef and 25 frozen minced beef (all samples 75) were collected from markets located in Mansoura. The samples were transferred to the laboratory in an ice box to be examined chemically. Frozen samples were thawed by over night refrigeration. Each sample was examined chemically as cited below.

\section{Chemical Examination}

- Determination of hydrogen ion concentration $(\mathrm{pH})$ : according to Pearson (1984).

- Determination of total volatile basic nitrogen (TVBN) $\mathrm{mg} / 100 \mathrm{gm}$. It was done according to FAO (1992).

- Determination of thiobarbituric acid (TBA) $\mathrm{mgMD} / \mathrm{kg}$. It was done according to Pikul et al. (1983).

- Heavy metals analysis: digestion of the samples, the frozen samples were defrosted then digested according to the recommended method Al-Ghais, (1995). A Perkin Elmer model (Spectra-AA 10, USA) 
flame atomic absorption spectrometer (AAS) with computer system was employed throughout the experiment for determination of lead cadmium and mercury. The concentrations of heavy metals in the solutions were determined by AAS which was adjusted at wave lengths of $283.3 \mathrm{~nm}, 228.8 \mathrm{~nm}$ and $253.7 \mathrm{~nm}$ for $\mathrm{Pb}, \mathrm{Cd}$ and $\mathrm{Hg}$ respectively. Absorbance and concentration were recorded on the digital scale of the AAS. The examined samples were calculated as ppm (mg/kg) on wet weight Seady (2001).

- Determination of organophosphrus (OP) pesticides were conducted by using HPLC apparatus (ISCO model 2350) HPLC and 205 UV/vis detectors. With hypersil HPLC column 250X4.6 mm BDs 18 OC5M. Samples were extracted and the pesticides residues were determined according to A.O.A.C. (1980) and Pesticide Analytical Manual PAM. (1994). The statistical analysis was carried out following the method described by Kirkwood (1989).

\section{RESULTS}

Table 1: Some heavy metals concentration ( $\mathrm{ppm})$ in the examined meat and meat products samples.

\begin{tabular}{|c|c|c|c|}
\hline Frozen minced meat & Frozen meat & Fresh meat & Parameters \\
\hline 0.032 & 0.045 & 0.067 & Lead \\
\pm 0.003 & \pm 0.003 & \pm 0.005 & \\
\hline 0.025 & 0.035 & 0.046 & Cadmium \\
\pm 0.003 & \pm 0.004 & \pm 0.006 & \\
\hline 0.004 & 0.006 & 0.008 & Mercury \\
\pm 0.0003 & \pm 0.0004 & \pm 0.0005 & \\
\hline
\end{tabular}

Table 2: Some biochemical analysis of the examined meat and meat products samples.

\begin{tabular}{|c|c|c|c|}
\hline Frozen minced meat & Frozen meat & Fresh meat & Parameters \\
\hline 6.3 & 6.4 & 5.8 & $\mathrm{pH}$ \\
\pm 0.3 & \pm 0.3 & \pm 0.2 & \\
\hline 20.5 & 21.6 & 12.5 & TVB-N mg $/ 100 \mathrm{gm}$ \\
\pm 2.1 & \pm 2.2 & \pm 1.2 & \\
\hline 0.664 & 0.713 & 0.275 & TBA mg MD $/ \mathrm{kg}$ \\
\pm 0.03 & \pm 0.04 & \pm 0.02 & \\
\hline
\end{tabular}

Table 3: Mean values of organophosphorus insecticides residues (ppm) 
in the examined meat and meat products samples.

\begin{tabular}{|c|c|c|c|}
\hline Frozen minced meat & Frozen meat & Fresh meat & Parameters \\
\hline 0.03 & 0.05 & 0.07 & Malathion \\
\pm 0.003 & \pm 0.004 & \pm 0.005 & \\
\hline \multirow{2}{*}{ Not detected } & 0.03 & 0.02 & Dimethoate \\
\hline 0.002 & \pm 0.003 & \multicolumn{2}{|c}{} \\
\hline
\end{tabular}

\section{DISCUSSION}

Beef may be exposed to high quality of toxic metals in the environment by air, water and ingestion of polluted feed Carl (1991). Feeding animals with forage produced in contaminated area results in increasing the concentration of each heavy metals consequently meat and milk production Jarup (2003); Tairova (2001); Massani et al. (2001). In the present study, Table 1 showed that the mean lead $(\mathrm{Pb})$ concentration was $0.067,0.045$ and $0.032 \mathrm{ppm}$ in fresh meat, frozen meat and frozen minced meat samples respectively. These results were in agreement with Salisbury et al. (1991); Spaulding (1975). While Ibrahim and Hasanain (2001) found that the mean value of lead concentration in beef was $0.885 \pm 0.062$ and Falandysz and Lorence, (1991) found that the mean value of lead in fresh beef was $0.080 \mathrm{ppm}$. Lead is recognized as known neurotoxicant and of major public health concern which causes both acute and chronic intoxication Gossel and Bricker (1990).

Toxic effects of lead involve the nervous system, liver and kidney function, blood circulation, and endocrine system Gossel and Bricker (1990). The provisional weekly intake of lead in food must not exceed $0.005 \mathrm{ppm}$ as recommended by FAO/WHO (1989). Lead poisoning is generally ranked as the most common environmental health hazard (Goyer, 1991; Adekunle and Akinyemi, 2004). Regarding to cadmium concentration. Table (1) showed the means of 0.046, 0.032 and $0.025 \mathrm{ppm}$ in fresh meat, frozen meat and frozen minced samples respectively. While El-Atabany (1995) measured the levels of cadmium in fresh meat which was $0.11 \mathrm{mg} / \mathrm{kg}$ wet weight. The presence of cadmium in meat may be attributed to grazing of animals on sandy or textured soil phosphate fertilizers contained a high amount of cadmium (Gradjean, 1986; Marcombe et al., 1994). Great ingestion of contaminated feeds, water and inhalation of fumes and dusts form the industrial activates results in high concentration of cadmium in tissues of 
lactating and beef animals Dwivedi et al. (1997). Cadmium is a cumulative poison and metabolically inhibits essential metabolic function of zinc, copper and iron furthermore; it inhibits sylphydral enzyme systems necessary for cellular metabolism (Mousa and Samaha, 1993). Concerning mercury concentration the means were 0.008, 0.006 and $0.004 \mathrm{ppm}$ in fresh meat, frozen meat and frozen minced meat samples respectively.

Jorhem et al. (1991) recorded that the mean value of mercury in meat was $0.005 \mathrm{mg} / \mathrm{kg}$. Mercury is considered a cumulative poison because of its slow excretion through the intestine and kidney Cang et al. (2004). The variation observed in the level of mercury concentrations in the present study may be attributed to different pasture, amount and types of offered to animals. Excessive sludge as soil fertilizers may be of a direct cause of the elevated mercury residues in tissues of cattle Falandysz and Lorenc (1991).

Table 2 showed that the $\mathrm{pH}$ of fresh meat, frozen meat and frozen minced meat was of the means 5.8, 6.4 and 6.3 respectively. $\mathrm{pH}$ value of meat according to (The Egyptian Standards 1991, 2005) is 5.6-6.2. The obtained data of fresh meat are within the permissible limits. Meanwhile $\mathrm{pH}$ of frozen meat and frozen minced meat were exceed the permissible limits according to (The Egyptian Standards 1991, 2005).

The increase in $\mathrm{pH}$ value during freezing storage indicate bacterial growth and possible spoilage of meat, such increase may be partly attributed to the production of volatile basic compounds such as ammonia (Putro et al., 1985; Galli et al., 1993). The obtained results in table 2 showed that the means total volatile basic nitrogen of the examined samples of fresh meat, frozen meat and frozen minced meat were $12.5,21.6$ and $20.5 \mathrm{mg} / 100 \mathrm{gm}$ respectively. The results revealed an increase of total volatile basic nitrogen during storage and freezing time in addition to such increase exceeded the suggestive limits recommended by the Egyptian Standards EOS, (1991). Nearly similar results were obtained by Barile et al. (1985).

Sharma and Goswami (2010) stated that the increase of TVBN values of market samples reflected their poor quality and unhygienic market conditions. TVBN determination was considered the most objective method for determining freshness Fontes et al. (2007).

Dealing to thiobarbituric acid (TBA) mean values of the examined fresh meat, frozen meat and frozen minced meat, they were $0.275,0.713$ and $0.664 \mathrm{mg} / \mathrm{kg}$ respectively. Values of the examined frozen samples were close to the suggested limits of TBA recommended 
by The Egyptian Standards EOS, (1991).

Rancidity may be developed during frozen storage of an underutilized medium fat content of frozen horse Mackerel, this was concluded by Santiago et al. (2002). An increase in thiobarbituric acid with an increase of frozen storage times was noted.

Table 3 showed that the malathion level concentrations of fresh meat, frozen meat and frozen minced meat were of means $0.07,0.05$ and $0.03 \mathrm{ppm}$ respectively, while dimethoate level concentrations were of means $0.02,0.03 \mathrm{ppm}$ in fresh meat and frozen meat but not detected in frozen minced meat samples. These samples were lower than that reported by Mostafa et al. (2007).

From the above mentioned, we concluded that the increase of $\mathrm{pH}$ value during freezing storage time may be partly attributed to the production of the volatile basic compounds and increasing of thiobabituric acid (TBA) value by increasing freezing storage time. The laboratories performing the analysis must be accredited according to the ISO standards, so freezing of meat must be under hygienic measures, and must be examined frequently.

\section{REFERENCES}

A.O.A.C. (1980): Official Methods of the Association. Officail Analytical Chemists, Washington D.C. Chapter 29 (pesticides) Bed.

Adekunle, I.M. and Akinyemi, N. (2004): Lead levels of certain consumer products in Nigeria. Study of smoked fish foods. Abeokuta. Food and Chemical Toxicology. 42: 1463-1468.

Al-Ghais, S.M. (1995): Heavy metal concentration in the tissue of Sparus Sarba Forskal. 1775 from the United Arab Emarates. Bull. Environ. Contam. Toxicol. 55: 581.

Barile, I.E.; Milla, A.D.; Reilly, A. and Villadsen, A. (1985): Spoliage patterns of Mackerel "FAO" Fisheries Rep. No. 317, PP. $23-40$.

Cang, L.Y.J.; Wang, D.M. and Dong, Y.H. (2004): Heavy metal pollution in poultry and livestock feeds and manures under intensive farming in Jiangsu Province, China. Journal of Environmental Sciences (China), 16: 371-374.

Carl, M.F.T. (1991): Heavy metals and other trace elements monograph on residues and contaminants in milk and milk products chapter 6. Int Dairy Federation, Belgium.

Dwivedi, S.K.; Swarup, D. and Day, S. (1997): Cadmium in bovine milk 
from different industrial localities of India. Ind. J. Animal Science 67(9): 758-769.

Egyptian Standards (1991): Frozen meats. Number1522. Egyptian Organization for Standardization and Quality

Egyption Standards (2005): Frozen poultry and rabbits. Number 1090. Egyptian organization for standardization and Quality Control.

El-Atabany, I.A. (1995): Cadmium and lead residues in some food animal tissues at Manzala abattoir. Zagazig Vet. J. 23(5): 90- 101

Falandysz, J. and Lorenc-Biala, H. (1991): Metal in muscle tissue liver and kidney of slaughtered animal from the Northen region of Poland. Bromatol. Chem. Toskyol 22: 19-22

FAO (1992): Manual of Food Quality Control. Part 4. Food and Agriculture Organization of United Nation, Rome.

FAO/WHO, Joint Expert Committee and Food Additives (1989):

Evaluation of certain food additives and contaminants. WHO Technical Series No, 778 Geneva.

Fleischer, M.; Sarofim, A.F.; Fassett, D.W.; Hammond, P. and Shacklette, H.T. (1974): Environmental impact of cadmium. A Review by the Panel on hazardous trace substances. In R. Goyer and H Falk, Ed. Environ. Health perspect. Exp. Issue No. 7 P. 253. Health, Education and Welfare. Nat Inst. Environ Health Sci.

Fontes, M.C; Esteves, A.; Coldeira, F.; Saraiva, C.; Vieira-Pinto, M. and Martins, C. (2007): Freshness and hygienic quality of fish sold in Portuguese Town. Arquivo Brasileiro de Medicina Veterinarae Zootecnia. 59: 5, 1308-1315.

Galli, A.I.; Franzetti, S.; Carelli, I.; Piergiovanni, R. and Fava, P. (1993): Microbiological Quality and Shelf Life of Chilled Cod Fillets in Vacuum- Skin and Modified Atmosphere Packaging. Pack Technol. Sci. 6: 147-157.

Gossel, T.A. and Bricker, J.D. (1990): Metal in Principals of Clinical Toxicology $2^{\text {nd }}$ ed. Raven Press, New York. pp: 623-680.

Goyer, R.A. (1991): Toxic effects of metals in Amdur M.O. Douli, J., Klansmen, C.D. (Eds.) Caserrett and Doull's Toxicology: The Basic Science of Poisons, fourth ed. Pergamon Press New York pp: 623-680.

Gradjean, P. (1986): Diseases associated with metals in Public Health 
and Preventive Medicine. $23^{\text {rd }}$ Ed. New York. Conn. Appleton Century Crofts, PP. 587.

Gunn, S.A. and Gould, I. (1957): Selective accumulation of Cd 115 by cortex of rat kidney Proc. Soc. Exp. Biol. Med 96: 820- 825

Ibrahim, H.M. and Hasanain, F.S. (2001): Public health hazard of beef at high ways $1^{\text {st }}$ Cong of Food Hygiene and Human Health. February. Dept of Food Hygiene. Fac. Vet. Med. Assiut Univ., Assiut- Egypt.

Jarup, L. (2003): Hazards of heavy metal contamination. British Medical Bulletin, 68: 167-182.

Jorhem, L.; Slorach, S.; Sundstron, B. and Ohlin, B. (1991): Lead, cadmium, arsenic and mercury in meat, liver and kidney of sweish pigs and cattle in 1984-1988. Food Additive Cont. 8(2): 201-212.

Kirkwood, B.R. (1989): Essentials of Medical Statistics, Blackwell Scientific Publication. 2nd ed. P. 151.

Klauder, D.S. and Petering, H.G. (1975): Protective value of dietary copper and Iron against some toxic effects of lead in rats. Environ. Health Prespect. 12:77.

Lars, J. (2003): Hazards of heavy metal contamination. British Bulletin, 68: $167-182$.

Lucis, O.J.; Lucis, R. and Shaikh, Z. (1972): Cadmium and Zinc in pregnancy and lactation. Arch. Envir. Health. 25: 14.

Marcombe, P.W.; Petterson, R.E.; Masters, H.G.; Ross, P.J. and Edwards, J.R. (1994): Cadmium concentration in kidney of sheep and cattle in Western Australia. Australia Agric. Res. 45(4): 851-862.

Massade, A.M. and Snook, R.D. (2002): Determintion of $\mathrm{Pb}$ and $\mathrm{Cd}$ in road dusts over period in which $\mathrm{Pb}$ was remain from petrol in the UK. Journal Environmental Monitorin, 4: 567-572

Massani, P.P.; Nad, R. and Toman, J.K. (2001): Concentrations of cadmium, lead nickel, copper and zinc in various muscles of Austrian. Journal of Agricultural Research, 52: 56-62.

Mostafa, M.H.; Mohamed, F.H. and Omaima, M.E. (2007): Hygienic status and prevalence of heavy metals and peasticides residues in frozen meat, chicken and their products in Luxor. Assiut Vet. Med. J. 53, 114: 91-105.

Mousa, M.M. and Samaha, I.A. (1993): Cadmium, copper, lead and zinc in carcasses in food animal. J. Vet. Sci., 9(3): 127-131.

O'Malley, M. (1997): Clinical evaluation of Pesticides exposure and 
poisoning. Lancet, 349: 1161-1169.

Pearson, D. (1984): Chemical Analysis in Foods. 8th Ed., Ronald's Kirk, Ronald Sawyer, Eagan.

Pesticide Analytocal Manual PA M. (1994): Deponent of Health and Human Services food and Drug Administration. Vol. 1, $3^{\text {rd }}$ ed. U.S.A.

Pikul, J.; Leszezynski, D.F. and Kummerow, F. (1983): Elimination of sample auto-oxidation by butylated hydroxytoulene. J. Agric. Food Chem. 31: 1338-1342.

Putro, S.; Saleh, M. and Bandolutmoto, B.S. (1985): Storage life of rabbit during icing FAO Fisheries Rep. NP. 317 (suppl.) 54-61

Salisbury, C.D.C; Chan, W. and Saschenbrecker, P.W. (1991): Multielemnt concentrations in liver and kidney tissues from five species of Canadian slaughtered animals. J. Assoc. Off. Anal. Chem. 74: 587-591

Santiago, P.A.; Ines, L. and Jose, M. (2002): Effect of previous storage on rancidity development in frozen Horse Mackerel. J. Sci. Food Agric. 852(15): 1764-1771.

Seady, N.I. (2001): Evaluation of heavy metals in meat and offals of variousanimal species slaughtered in Menoufia Governorate PH D thesis, Faculty of Veterinary Medicine. Moshtohor, Zagazig University Banha Branch.

Sharma, P.J. and Goswami, U.C. (2010): Quality of commercially dried fresh water fish of Assam Source. Environment and Ecology. 28: 2A, 1163-1165.

Spaulding, J.E. (1975): Unpublished data USDA-APHIS, Washington DC.

Tairova, A.R. (2001): The use of chitozan for adjusting heavy metals in products of cattle slaughter. Zootechnices, 9: 27-29 (RU).

Turi-szerletics, M.M. and Patko, I. (2008): Environmental Contaminants in Food Stuffs. Acta Polytechnica Hungarica. 5, 3: 135-140.

Underwood, E.J. (1977): Trace elements in human and animal nutrition. $4^{\text {th }}$ ed. Academic Press, New York.

Willoughby, R.A. Thawley, D.G. and Brawn, G. (1976): Interactions of lead with other trace substances and dietary factors. Arch. Indust. Hyg. Toxic. (Yougoslavia) 26:29. 